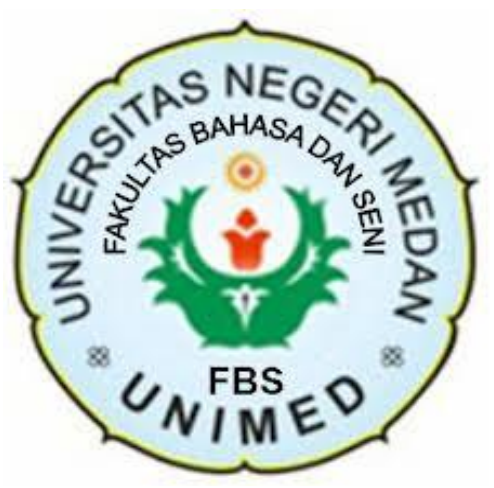

ENGLISH AND LITERATURE DEPARTMENT FACULTY OF LANGUAGES AND ARTS STATE UNIVERSITY OF MEDAN 2017 
ARTIKEL

\section{STUDENT TALK IN ENGLISH CLASSROOM INTERACTION}

\section{AT SMA NEGERI 2 BINJAI}

Disusun dan Diajukan oleh:

Windi Love Pita Sari

NIM. 2123321087

Telah diverifikasi dan dinyatakan memenuhi syarat untuk diunggah pada jurnal online

Medan, Juli 2017

Menyetujui
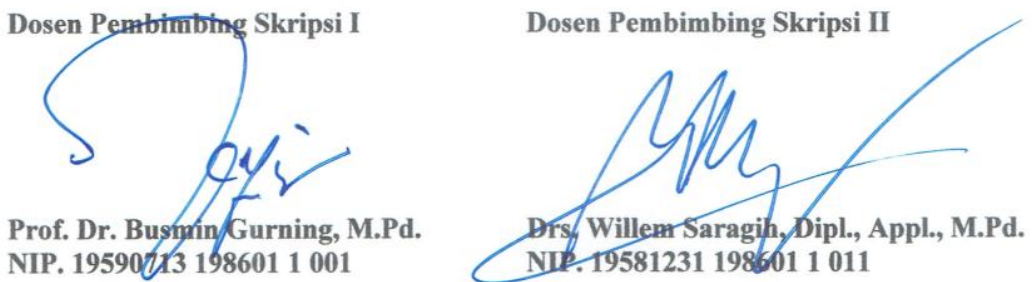

Ka. Program Studi

Pendidikan Bahasa Inggris

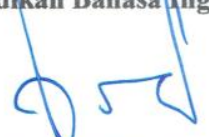

Nora Ronita Dewi, S.Pd., S.S., M.Hum.

NIP. 198005222008122003 


\title{
STUDENT TALK IN ENGLISH CLASSROOM INTERACTION AT SMA NEGERI 2 BINJAI
}

\author{
*Windi Love Pita Sari \\ **Busmin Gurning \\ **Willem Saragih
}

\begin{abstract}
Sari, Windi Love Pita. NIM 2123321087. Student Talk in English Classroom Interaction at SMA Negeri 2 Binjai. A Thesis. Faculty of Languages and Arts, State University of Medan. 2017.

This study was aimed at finding out the types of student talk, the dominant type of student talk and the reasons why the students used the dominant type of student talk during teaching-learning process at SMA Negeri 2 Binjai in 2016/2017 academic year. This qualitative research used 40 students in grade XII as the source data and the researcher used audio recording, observational tally sheet, and matrix as the instruments for collecting data. The data got by using Flanders Interaction Analysis Category (FIAC). The analysis showed that students were still passive in speaking in the classroom interaction. The total percentage of student talk was $36,44 \%$. The percentages of student talk in the first meeting were: $11,63 \%$ of student talk-response and $9,42 \%$ of student talk-initiation. Then, the percentages of student talk in the second meeting were: $11,35 \%$ for student talkresponse and $4,04 \%$ for student talk-initiation. The dominant type of student talk was student talk-response by $22,98 \%$. The researcher found the reasons by interviewing the students. The reasons why the students used the dominant type student talk-response were: (a) responding to the teacher's question was the obligation of the students, (b) the students were understood and interested with the topic, (c) the students want to increase their ability in speaking English because the students seldom speak English outside of classroom, (d) some students do not speak confidently in the class, so by responding to the teacher will build up their confidence, (e) the students want to increase their ability in speaking English in order to build up their confidence, (f) by responding to the teacher's question, it made the students more active in the classroom.
\end{abstract}

Keywords: classroom interaction, student talk, Flanders Interaction Analysis Category (FIAC).

\footnotetext{
*Graduate Status

**Lecturer Status
} 


\section{INTRODUCTION}

\section{Background of the Study}

The ability of human to talk to use language in order to communicate with each other is so universal. By using language people can communicate with people from the other places. Language is the important element for people to make a communication because by using language we can understand about what people say without misunderstanding. The activity of process of expressing ideas and feelings or giving information is called communication, Hornby (2000: 225). It means by communication people can exchange ideas or opinions, people also can give information to the others, so they can share information that they get from many sources. Furthermore with communication people can express their feelings.

According to Smith in Hill (1969: 103) language is a learned, shared, and arbitrary system of vocal symbol through which human beings in the same speech community or subculture interact and hence communicate in terms of their common culture experiences and expectation. From that definition we know that language is the communication system which is complex and flexible to deserve by human beings to make an interaction as human social.

English is one of the languages in this world and English is also an international language which is very important for students to learn English. As the important language, English is also one of the subjects in senior high school. In Indonesia, English is as a foreign language (EFL) that is why teaching English in Indonesia is not easy. The students start to learn English from elementary 
school until senior high school, it means the students should be able to speak English well, but in fact it is still far from the expectation of teacher because the ability of students to speak English is still low. In the classroom interaction the students talking time should be around $70 \%-80 \%$ because the students need to practice their ability in speaking English, and the teacher talking time should be around 20-30\%. Tsegaye and Davidson (2014:5) say that in communicative EFL classes students need ample opportunity to practice the target language so that the teacher should reduce the amount of their talk to $20 \%$ to $30 \%$ of the class time, and Student Talk Time should be around $70 \%$ to $80 \%$ during the lesson time. In the reality, in classroom interaction the teacher is always dominant or higher than that percentage to talk in the class than the students.

Furthermore, based on the researcher observation in third grade at SMA Negeri 2 Binjai, the researcher found that the students more active to speak in speaking lesson if the teacher gave the chance for the students to speak English.

Teacher : ok Fikri, what will you do if you can go to Seattle?

Student : I will take a picture sama jalan-jalan ke tempat bagus mam. Teacher : He wants to travelling ya.

From the preliminary data above, despite the vocabularies of the students are still low, but they will try to speak if the teacher gives the opportunity to speak for them. It means that the ability of students to speak English is influenced by the teacher who should give a chance for students to practice their English. When the teacher gives a chance for students to share their idea, share information to other 
students, or answer the question from the teacher, they will be accustomed to speak English.

Furthermore, Yuanfang (2009) states that English as a foreign language in classroom does not have social function for EFL students' everyday life. It means that the students seldom speak English with their friends outside of classroom because they do not have partner to practice English in their daily life. That is why classroom is the important educational institution for students to practice their English. Classroom is considered as a vital source of foreign language learning where the students can be provided by language input and modeling so that they can practice in interaction, Xiao (2006: 13). Classroom is very important place for students to practice their ability to speak English because in the classroom they can make an interaction with other students and teacher. In addition according to Kumpulainen and Wray (2002: 9) during its early phase educationally oriented research into classroom interaction focused mostly on whole-class interactions between the teacher and students.

Classroom interaction is the activity between teacher and students who participate to talk during teaching and learning process. In fact, according to Kumpulainen and Wray (2002: 9) in this interaction sequence, during which the teacher often tightly controls the structure and content of classroom interaction, the teacher initiates the discussion by posting question. Furthermore, according to Flanders in Raths, Pancella, and Van (1970: 43) if someone is talking, the chances are that it will be the teacher more than 70 per cent of the time. It means that the 
teacher is always dominant in the classroom interaction and it makes the students become passive to speak in the classroom.

In addition, there are some researches about classroom interaction. First, the research from Nurmasitah (2010) entitled "A Study of Classroom Interaction Characteristics in A Geography Class Conducted in English: The Case at Year Ten of An Immersion Class in SMA N 2 Semarang" found that 1) the most dominant characteristic in immersion classroom interaction was the content cross (the most of the teaching-learning time was devoted to questions and lectures by the teacher), 2) the teacher spent $57.43 \%$ of teaching-learning time, while the students spent $22.02 \%$ of the teaching-learning time that showed that the students were active enough in the classroom interaction, 3) the teaching effectiveness elements used in the classroom were in the form of academic learning time, used of reinforcement, cues and feedback, co-operative learning, classroom atmosphere, higher order questions, advance organizer, direct instruction, indirect teaching, and the democratic classroom. The last is the research of Triani (2013) entitled "Classroom Interaction: An Analysis of Teacher Talk and Students Talk in English for Young Learners (EYL)" found that 1) classroom interaction revealed teacher talk was as dominant aspect compared with students talk and silence. 2) The dominance of teacher talk proportion in each meeting happened since the teacher mainly explained grammatical rules and gave instructions on writing tasks. 3) The teacher spent $56.99 \%$ to talk during the classroom interaction, students spent $32.56 \%$ to talk during the classroom interaction, and silence $21.57 \%$. 
Moreover, when the researcher observed teaching-speaking in third grade who taught by the teacher at SMA Negeri 2 Binjai, the researcher found that the students were passive in speaking because the teacher is too dominant in the classroom. That is the basic reason why the researcher wants to know the students talk during English classroom interaction.

Based on the issues above the researcher wants to analyze student talk in verbal classroom interaction. The researcher wants to know the percentage of students talk in the classroom interaction based on Flanders' Interaction Analysis Category (FIAC). FIAC is a Ten Category System of communication which said to be inclusive of all communication possibilities. There are seven categories in teacher talk (accepts feeling, praises or encourages, accepts or uses ideas of student, asks question, lecturing, giving direction, criticizing or justifying authority), two categories of student talk are (students talk-response, students talkinitiation), and one category is silence or confusion.

Based on the explanation above, the researcher wants to conduct a research entitled "Student Talk in English Classroom Interaction at SMA Negeri 2 Binjai."

\section{REVIEW OF LITERATURE}

\section{Definition of Classroom Interaction}

In the classroom, interaction is the communication between teacher and students and also between students and students. According to Tsui (2001: 120) classroom interaction refers to interaction between teacher and learners, and amongst the learners, in the classroom. It means that classroom interaction is all 
the interaction that occurs in teaching and learning process. In classroom interaction, the students have chance to speak and to share their ideas. When the students have chance to speak in the classroom, it means that they can increase their ability in language. Through interaction, students can increase their language store as they listen to or read authentic linguistic material, or even output of their fellow students in discussions, skits, join-problem solving task, or dialogue journal, Brown (2000: 165).

\section{Flanders Interaction Analysis Category (FIAC)}

Flanders Interaction Analysis Category (FIAC) is the system to analyze all activity that happens in teaching and learning process. FIAC has three categories to provide in classroom interaction, they are teacher talk, students talk, and silence or confusion. Student talk can be divided into two categories, they are student talk-response and student talk-initiation.

Classroom interaction by Flanders (1970)

Table 2.1. Flanders Interaction Analysis Categories (FIAC)

\begin{tabular}{|c|c|c|}
\hline $\begin{array}{l}\text { Teacher } \\
\text { Talk }\end{array}$ & $\begin{array}{l}\text { Indirect } \\
\text { Influence }\end{array}$ & $\begin{array}{l}\text { Accepts Feeling: } \\
\text { Accepts and clarifies the tone of feeling of the students in an unthreatening } \\
\text { manner. Feelings may be positive or negative. Predicting and recalling } \\
\text { feelings are included. } \\
\text { Praises or Encourages: } \\
\text { Praises or encourages student action or behavior. Jokes that release tension, } \\
\text { but not at the expense of another individual; nodding head saying "um } \\
\text { hm?" or "go on" are included. } \\
\text { Accepts or Uses Idea of Student: } \\
\text { Clarifying, building or developing ideas suggested by a student. As a } \\
\text { teacher brings more of his own ideas into play, shift to category } 5 \text {. } \\
\text { Asks Questions: } \\
\text { Asking a question about content or procedures with the intent that the } \\
\text { student will answer. }\end{array}$ \\
\hline & & $\begin{array}{l}\text { Lecturing: } \\
\text { Giving facts of opinions about content or procedures; expressing his own }\end{array}$ \\
\hline
\end{tabular}




\begin{tabular}{|l|l|l|}
\hline \multirow{2}{*}{$\begin{array}{l}\text { Teacher } \\
\text { Talk }\end{array}$} & $\begin{array}{l}\text { Direct } \\
\text { Influence }\end{array}$ & $\begin{array}{l}\text { ideas, asking rhetorical question. } \\
\text { Giving Direction: } \\
\text { Directions, command, or others to which students are expected to comply } \\
\text { with. } \\
\text { Criticizing or Justifying Authority: } \\
\text { Statements intended to change student behavior from unacceptable to } \\
\text { acceptable pattern; bawling someone out; stating why the teacher is doing } \\
\text { what he is doing what he is doing; extreme self-references. }\end{array}$ \\
\hline \multirow{3}{*}{$\begin{array}{l}\text { Student } \\
\text { Talk }\end{array}$} & Response & $\begin{array}{l}\text { Student Talk-Response: } \\
\text { Talk by student in response to teacher. Teacher initiates the contact or } \\
\text { solicits student statement. }\end{array}$ \\
\cline { 2 - 4 } Silence & Initiation & $\begin{array}{l}\text { Student Talk-Initiations: } \\
\text { Talk initiated by student. If "calling on" student is only to indicate who } \\
\text { may talk next, observer must decide whether wanted to talk. }\end{array}$ \\
\hline $\begin{array}{l}\text { Silence or Confusion: } \\
\text { Pauses, short periods of silence and periods of confusion in which } \\
\text { communication cannot be understood by the observer. }\end{array}$ \\
\hline
\end{tabular}

\section{RESEARCH METHODOLOGY}

\section{Methodology}

This research was conducted by using qualitative research. Cohen, Manion, and Morrison (2007: 461) state that qualitative data analysis involves organizing, accounting for and explaining the data; in short, making sense of data in terms of the participants' definitions of the situation, noting patterns, themes, categories and regularities.

\section{Techniques of Data Analysis}

The data were calculated by the researcher after collecting the data. After the researcher found the data from observation tally sheet based on Flanders' Interaction Analysis Category (FIAC), the data completed to find out the percentage of student talk by using Flanders' formula (1970 as cited in Putri 2014). 
Here were the formulates:

1. Percentage of Student Talk (ST)

$$
S T=\frac{c 8+c 9}{N} \times 100 \%
$$

2. Percentage of Student Talk-Response (STR)

$S T R=\frac{\mathrm{c} 8}{\mathrm{~N}} \times 100 \%$

3. Percentage of Student Talk-Initiation (STI)

$$
S T I=\frac{\mathrm{c} 9}{\mathrm{~N}} \times 100 \%
$$

\section{Procedure}

The procedures of this research were conducted in these following steps:

Step 1: Deciding the code of teacher talk and student talk

The researcher came to the class and sat in the backside. Then the researcher prepared the audio recording to record the interaction that occurs in teaching and learning process in the classroom. After that the researcher was helped by co-researcher to put out the code in observation tally sheet in order to get the data.

Step 2: Plotting the code of numbers in pair

Then, after the researcher got the number, the researcher plotted the number in a pair and put the same number (number 10) in the beginning and ending. After that, the researcher found the sequence of pair from the number. 
Step 3: Interpreting the pair into FIAC's Matrix

Next, after the researcher had found the pair of number the researcher interpret the number into matrix of Flanders Interaction Analysis System.

Step 4: Calculating the teacher talk and student talk

The last step was to calculate the teacher talk and student talk during teaching and learning process by Flanders' formula and to find out the dominant type of student talk that was used by the students.

Step 5: Interviewing the students

Then, after the researcher find the dominant type of student talk the researcher interviews the students to find out the reason why the students use the dominant type of student talk.

\section{FINDINGS AND DISCUSSIONS}

\section{Findings}

After the data have been analyzed, the researcher found both students talkresponse and student talk-initiation occur in classroom interaction during teaching learning process. Here are the percentages of student talk:

\begin{tabular}{|c|c|c|c|c|}
\hline \multirow[t]{2}{*}{ Types } & \multirow[t]{2}{*}{ Formulates } & \multicolumn{2}{|c|}{ Meeting } & \multirow[t]{2}{*}{ Total } \\
\hline & & First & Second & \\
\hline $\begin{array}{l}\text { Student Talk- } \\
\text { Response }\end{array}$ & $S T R=\frac{\mathrm{C} 8}{\mathrm{~N}} \times 100 \%$ & $S T R=\frac{84}{722} \times 100 \%$ & $=S I I R 63 \% \frac{73}{643} \times 100 \%=$ & $\begin{array}{r}22,98 \% \\
11,35 \%\end{array}$ \\
\hline $\begin{array}{l}\text { Student Talk- } \\
\text { Initiate }\end{array}$ & $S T I=\frac{\mathrm{C} 9}{\mathrm{~N}} \times 100 \%$ & $S T I=\frac{68}{722} \times 100 \%=$ & $=9 \pi 42 \% \frac{26}{643} \times 100 \%=$ & $+13,46 \%$ \\
\hline & Total & $21,05 \%$ & $15,39 \%$ & $36,44 \%$ \\
\hline
\end{tabular}


The table shows the percentage of student talk during teaching and learning process in the classroom interaction. Based on the percentage, the researcher finds that the students are still passive to talk in the classroom. By knowing that percentage, the researcher finds that the interaction between teacher and students in the classroom is not ideal because the students are passive to talk in the class. A good interaction in the class is when teacher talk time around $20 \%$ $30 \%$ and students talk time around $70 \%-80 \%$, yet from that percentage the students talk time in the first and second meeting are $15,39 \%-21,05 \%$.

In addition, student talk-response is more dominant than student talkinitiation by the percentage $22,98 \%$. Student talk-response as the dominant type of student talk because the students think that answer or respond to the teacher's question is the obligation of the student because it shows that the students respect the teacher. Then, the students who respond to the teacher will make the students build their confidence to speak in the class and the students can also practice their ability in speaking English. Furthermore, when the students respond to the teacher, the students will make teaching and learning process more active in the class. In addition, the students hope that they can speak English well by responding to the teacher and build their ability in speaking English.

\section{Discussions}

Based on the result both student talk-response and student talk-initiation occur in teaching-learning process but the students are still passive to talk in the class. The percentage of student talk in the classroom is still low or the students are still passive to talk in the classroom. According to Tsegaye and Davidson 
(2014: 5) in communicative EFL classes students need ample opportunity to practice the target language so that the teacher should reduce the amount of their talk to $20 \%$ to $30 \%$ of the class time, and Student Talk Time should be around $70 \%$ to $80 \%$ during the lesson time. In teaching and learning process, the students are the object of the study that the teacher must guide to be more active to participate in the class but in fact the teacher is more dominant to speak in the class. The students have little opportunity to practice and just learn passively, Tsegaye and Davidson (2014: 29). When the students are passive to talk in the class, it means the interaction between teacher and students is not ideal because a good interaction is when the students are active in participating to talk in the classroom. Furthermore, the percentage of student talk-response is more dominant than student talk-initiation. Based on that percentage, the researcher finds that the students are more active in responding to the teacher than the student must initiate to talk in the classroom interaction. The students will respond to the teacher or in other word the students will try to speak English in the class if the teacher gives the question for the students. Then, the students seldom initiate in classroom interaction because of some reasons, such as the students cannot speak English fluently, lack of vocabularies, and do not have confidence. Those reasons make the student just speak in the class if the teacher asks them because they are afraid to make a mistake when they speak in the classroom. According to Tsegaye and Davidson (2014: 44) a good teacher maximizes Student Talk Time and minimizes Teacher Talk Time. So, it is important for the teacher to talk more dominant in the 
class because in the classroom interaction the students need to learn and practice more in order to increase their ability in speaking English.

\section{CONCLUSIONS AND SUGGESTIONS}

\section{Conclusions}

After the data have been analyzed, the researcher concludes that:

1. All the types of student talk based on Flanders Interaction Analysis Category (FIAC), namely student talk-response and student talk-initiation occurred in teaching-learning process at SMA Negeri 2 Binjai. By the percentages of student talk in the first meeting were: $11,63 \%$ for student talk-response and $9,42 \%$ for student talk-initiation. Then, The percentages of student talk in the second meeting were: $11,35 \%$ for student talk-response and $4,04 \%$ for student talkinitiation.

2. The type of student talk dominantly used by the students is student talk-response by $22,98 \%$.

3. Student talk-response as the dominant type of student talk because the students think that the answer or response to the teacher's question is the obligation of the students and it shows that the students are respect to the teacher. Then, the students who respond to the teacher will make the students build up their confidence to speak in the class. In addition, when the students respond to the teacher, the students will make teaching and learning process more active in the class. Furthermore, the students hope that they can speak English well by responding to the teacher and build up their ability in speaking English. 


\section{Suggestions}

Related to the findings, there are suggestions as follows:

1. The interaction between teacher and students will make teaching and learning process in the classroom more active, but if the teacher is too dominant the students will be passive to talk in the classroom. The percentage of student talk shows that the students are still passive to talk in the class. By knowing that percentage, the teacher must know that when the teacher is too dominant to talk in the class, the teacher just gives little opportunities for the students to talk in the classroom. So, the teacher must realize that the teachers must decrease their talking time and increase the students talking time to make the students become active in the classroom.

2. The students just speak if the teacher gives the question for the students or in other words the student just respond and they seldom initiate or speak in the class if the teacher does not give the instruction for the students to speak. So, the students ought to be more active and confident to speak in the class based on their initiation to give their opinions about the topic.

3. The readers who are interested in conducting related study, on this study is expected to help and to give more information about classroom interaction.

\section{REFERENCES}

Amatiri, V. O. (2015). The Instructional: A Review of Flanders' Interaction Analysis in Classroom Interaction. International Journal of Secondary Education. Vol. 3(5): p. 43-49

Brown, H. D. (2000). Teaching by Principle: An Interactive Approach to Language Pedagogy, Second Edition. San Fransisco: Longman 
. (2007). Principle of Language Learning and Teaching, Fifth Edition. San Fransisco: Longman.

Carter, R. and Nunan, D. (2001). The Cambridge Guide to Teaching English to Speakers of Other Languages. United States of America: Cambridge

Cashdan, A. (1979). Language Reading and Learning. Great Britain: Oxford.

Cohen, L. M, L. Morrison, K. (2007). Research Method in Education. New York: Routledge

Fatimah, M. A. 2013. A Study of Teacher Talk and Students Talk in Verbal Classroom Interaction to Develop Speaking Skill for Young Learner. Journal of English and Education. Vol. 1(1), p. 1-10.

Garrett, T. (2008). Student-Centered and Teacher-Centered Classroom Management: A Case Study of Three Elementary Teachers. Journal of Classroom Interaction. Vol 43(1): p. 34-47

Hornby, A.S. (2000). Oxford Advanced Learner's Dictionary: Oxford University Press.

Houwer, J. D. Barnes, H. D. Moors, A. (2013). What is Teaching? On the Nature and Merits of a Functional Definition of Learning. Accessed on April, $10^{\text {th }}$ 2016.

Jarolimek, J. and Foster C. (1976). Teaching and Learning in the Elementary School. United States of America: Macmillan Publishing.

Kumpulainen, K. and Wray, D. (2002). Classroom Interaction and Social Learning: From Theory to Practice. New York: Routledge Falmer.

Lubis, Y. (1988). Developing Communicative Proficiency in the English as a Foreign Language (EFL) Class. Indonesia.

Nunan, D. (1999). Second Language Teaching \& Learning. Boston: Heinle \& Heinle.

Nurmasitah, S. (2010). A Study of Classroom Interaction Characteristics in A Geography Class Conducted in English: The Case at Year Ten of An Immersion Class in SMA $N 2$ Semarang. Semarang: Universitas Diponegoro

Putri, G. F (2014). An Analysis of Classroom Interaction by Using Flander Interaction Analysis Category System (FIACS) Technique at SMA 13 Kota Bengkulu in 2013/2014 Academi Year. Bengkulu: Universitas Bengkulu. 
Raths, J. P, Raths J. and Van, N. J. (1970). Studying Teaching. United State of America.

Smith, H. L. (1968). Language and the Total System of Communication in Archibald A. Hill. (Ed) Linguistic (p.103). United States.

Sugiyono. (2011). Metode Penelitian Pendidikan (Pendekatan Kuantitatif, Kualitatif, dan $R \& D$ ). Badung: Alfabeta

Suherdi, D. (2009). Classroom Discourse Analysis: A System Approach. Bandung: Celtics Press.

Triani, P. R. 2013. Classroom Interaction: An Analysis of Teacher Talk and Students Talk in English Young Learners (EYL). Journal of English and Education. Vol. 1(1), p. 163-172.

Tsegaye, A,G. and Davidson, L.M. (2014). The Ratio of Teacher Talking Time to Students Talking Time in EFL Classroom: A Case in Six Partner Preparatory School of Haramaya University Ethiopia. Visakhapatnam: India. Vol.3 no.5

Tsui, A.B.M. (1995). Introducing Classroom Interaction. London: Penguin.

Xiao, Y. (2006). Teacher Talk and EFL in University Classroom. China: Chongqing Normal University \& Yangtze Normal University.

Yuanfang, Yu. (2009). A Study of Foreign Language Learning Motivation and Achievement: From A Perspective of Sociocultural Theory. CERELA Journal, vol.32 no.3. 